\title{
PROBLEMATIKA PENDIDIKAN DI ERA GLOBALISASI (Telaah dari Aspek Lingkungan)
}

\author{
Oleh: Syarifudin
}

\begin{abstract}
Abstrak
Untuk menapai suatu tujuan penddikan tidak bisa telepasdari faktorfaktor yangsalingberkaitan satusama lain Salahsatunya adalah faktor lingkungandi manalingkungansendri mash salingmemberi pengruh antara satu dengan lainnya Lingkungan kduarca yangmeupakan tempat pertama anak mendapat pendidikan diharapkan dapatmembentuk aspek afektif (sikap meal dan mora). Lingkungan sekdah diharapkan dapat membentuk aspek kognitif (intektual) danlingkungan mesyarakat diharapkan dapatmenhentuk aspek psikomotorik (skill/ keteramplan) anak. Maka ketiga aspek terseaut adadalamlingkungan pandidikan

Penyelengaraan pendidikan adklahmenjadi tanggungjavab bessama antara keluarga mesyarakat dan pemeintah karena itu penddikan betanssung samur hidup (longlifeeduration) dan dilaksanakan di dalamlingkungan keluarca, sekdahdan mesyarakat. Pendidkankita terdni atas ticg bagian Petama, penddikaninfomal (kduarga), formi (skdah) dannonfomal (masyarakat). Sasaran yangingin dicapai dari penddikankita adkah pembentukan aspek kogitif (intdektual), afektif (sikapmental ataumord) danpsikamotorik (skill/ keteramplan). Idkelnya, pembentukanaspok kognitif mejadi tuges dan tangungjawab para pendidk (gun) di sekdah, pembetukan aspek edktifmerjad tuges dan tanggungjavab orangtuadan

penbentukan aspek psikomotorik menjadi tuges dan tangyungjauab masyarakat (lembagalembaga kursus, dansgienisnya).
\end{abstract}

Kata Kumi: Prdblematika Pendidikan, Aspok Lingkungan

\section{A. Pendahuluan}

Kegiatan pendidikan selalu berlangsung di dalam suatu lingkungan. D alam konteks pendidikan, lingkungan dapat diartikan sebagai segala sesuatu yang berada di luar diri anak. Lingkungan dapat berupa hal-hal yang nyata, seperti tumbuhan, orang, keadaan, politik, sosial-ekonomi, binatang, kebudayaan, 
kepercayaan, dan upaya lain yang dilakukan oleh manusia termasuk di dalamnya pendidikan.

Berbagai kenyataan modernitas dan ketersediaan tersebut faktanya tidak sulit bahkan setiap hari disediakan baik oleh keluarga, masyarakat dan juga dunia informasi. Maraknya dunia periklanan memaksa informasi beredar lebih mudah, lebih seronok dan juga lebih merangsang rasa ingin tahu, rasa ingin mencoba sebagai akibat "rayuan maut" publikasi yang memang dirancang secara apik oleh para ahli komunikasi dengan biaya yang mahal dan dengan dampak meluas dan mendalam. Dapat dikatakan informasi-informasi tersebut dapat lebih cepat hadir dan pada sarapan pagi kita, atau lebih cepat disantap dari pada nasehat orang tua.

Dalam aktivitas pendidikan ada enam faktor pendidikan yang dapat membentuk pola interaksi atau saling mempengaruhi namun faktor integratirnya terutama terletak pada pendidik yang dengan segala kemampuan dan keterbatasannya. Keenam faktor pendidikan tersebut meliputi: faktor tujuan, faktor pendidik, faktor peserta didik, faktor isi/materi pendidikan, faktor metode pendidikan dan faktor situasi lingkungan. ${ }^{1}$

\section{B. Pengertian Lingkungan Pendidikan}

Kegiatan pendidikan di manapun selalu berlangsung dalam suatu lingkungan tertentu, baik lingkungan yang berhubungan dengan ruang maupun waktu. Istilah lingkungan dalam arti yang umum adalah sekitar kita. Dalam hubungannya dengan kegiatan pendidikan, lingkungan dapat diartikan sebagai segala sesuatu yang berada di luar diri anak dalam alam semesta ini. Ada lingkungan yang dekat dan ada pula lingkungan yang jauh.

Lingkungan dapat berupa hal-hal yang dapat diamati seperti: tumbuhtumbuhan, binatang, orang-orang, dan sebagainya. Tetapi dapat pula lingkungan itu sebagai suatu hal di luar anak yang tidak ditangkap oleh indera kita karena sifatnya abstrak seperti: situasi ekonomi, politik, sosial, kepercayaan, adat istiadat, kebudayaan dan sebagainya. Pendidikan dalam artian ini adalah merupakan bagian dari lingkungan juga. Tetapi mengingat sifat pengaruh yang

${ }^{1}$ Fuad Ihsan, Dasar-Dasar Kepædidikan (Jakarta: Rinkka Cipta, 1996), hlm 8. 
diberikan oleh pendidik berbeda dari pengaruh yang diberikan oleh lingkungan, maka pendidik kita pisahkan dari lingkungan.

Lingkungan memberikan pengaruh yang besar kepada perkembangan anak didik, dan hal ini tidak sulit bagi kita untuk mencari contoh-contoh. Lingkungan dapat dikatakan sebagai "pendidikan yang tersembunyi", karena pengaruh lingkungan yang tidak sengaja tersebut besar juga kepada perkembangan anak didik. Masalahnya adalah bahwa justru anak didik lebih tertarik untuk mengikuti pengaruh yang dengan sengaja diberikan oleh pendidik dalam situasi kegiatan pendidikan. Ini memang merupakan masalah yang harus diatasi. Salah satu cara untuk mengatasinya adalah dengan mengusahakan lingkungan yang menantang dan merangsang kepada anak didik, dan yang dapat memberikan pengaruh yang positif kepada perkembangan mereka Misalnya kita mengusahakan adanya buku-buku bacaan yang baik untuk perkembangan segi-segi kejiwaannya: minat, intelek, akal, apresiasi dan sebagainya. Kita sendiri hendaknya menjadi suatu lingkungan yang positif kepada mereka: tindak tanduk kita, percakapan kita, kebiasaan kita, minat untuk belajar kita, dan sebagainya.2

Manusia dewasa (pendidik) dan manusia belum dewasa (anak didik) bersama-sama hidup dalam suatu kesatuan hidup tertentu di dalam suatu alam lingkungan sekitar (mlie)). Lingkungan sekitar mencakup :

1. Tempat (lingkungan fisik) : keadæan iklim, keadaan tanah, keadaan alam;

2. Kebudayaan (lingkungan budaya) : dengan warisan budaya tertentu: bahasa, seni, ekonomi, ilmu pengetahuan, pandangan hidup, keagamaan;

3. Kelompok hidup bersama (lingkungan sosial/masyarakat): keluarga, kelompok bermain, desa, perkumpulan.

Lingkungan sekitar mempengaruhi perkembangan anak. Lingkungan sekitar yang dengan sengaja digunakan sebagai alat dalam proses pendidikan (pakaian, keadaan rumah, alat permainan, buku-buku, alat peraga, dan lainnya),

${ }^{2}$ B. Sunyosibrto, Beberapa Aspk Dasar-Dasar Kependidikan (Jakarta: Rinkka Cipta, 1996), hlm 31. 
dinamakan lingkungan pendidikan.3 Lingkungan yang dengan sengaja diciptakan untuk mempengaruhi anak ada tiga, yaitu:

1. Lingkungan keluarga, keluarga merupakan lingkungan pertama bagi anak, di lingkungan keluarga pertama-tama anak mendapatkan pengaruh sadar. Keluarga juga merupakan kesatuan hidup bersama yang pertama dikenal oleh anak, dan karena itu disebut pimary community (lingkungan pendidikan utama). Karena itu merupakan lembaga pendidikan tertua, yang bersifat informal dan kodrati.

2. Lingkungan sekolah, sekolah merupakan lembaga sosial formal yang didirikan berdasarkan UU negara sebagai tempat/lingkungan pendidikan. Sekolah di satu pihak mewakili negara dan pihak lain mewakili orang tua/ masyarakat setempat. Di dalam kehidupan bersekolah anak meneruskan pendidikan yang sudah diterima olehnya di dalam keluarga, dan berusaha mengembangkan dirinya sebagai warga negara yang baik sesuai dengan nilai-nilai kemanusiaan yang menjadi pandangan hidup bangsa Negara.

3. Lingkungan masyarakat, masyarakat adalah salah satu lingkungan pendidikan yang besar pengaruhnya terhadap perkembangan pribadi seseorang. Pandangan hidup, cita-cita bangsa, sosial budaya dan perkembangan ilmu pengetahuan akan mewarnai keadaan masyarakat tersebut. Masyarakat mempunyai peranan yang penting dalam mencapai tujuan pendidikan nasional.4

Sartain $^{5}$ (seorang ahli psikolog Amerika) mengatakan bahwa yang dimaksud dengan lingkungan (eniroment) meliputi semua kondisi dalam dunia ini yang dengan cara-cara tertentu mempengaruhi tingkah laku kita, pertumbuhan, perkembangan atau life prosses kita kecuali gen-gen. Bahkan, gen-gen dapat pula dipandang sebagai menyaiapkan lingkungan (to proice enironmet) bagi gen yang lain.

${ }^{3}$ Tim Penyusn, Dasar-Dasar Ilmu Pendidikan Buku Panduan Mahasiswa (Jakarta: PT Gramela Pustaka Utama, 1996), hlm 39.

${ }^{4}$ Fuad Ihsan, Op Cit, hlm 32.

${ }^{5} \mathrm{M}$ Ngalim Purvanto, Ilmu Pendidikan Teenitis dan Praktis (Bandung PT. Remaja Rosckkarya, 2007), hlm 72. 
Menurut defenisi yang luas ini, ternyata bahwa di dalam lingkungan kita atau di sekitar kita tidak hanya terdapat sejumlah faktor pada suatu saat, tetapi terdapat pula faktor-faktor lain yang banyak sekali, yang secara potensial sanggup atau dapat mempengaruhi perkembangan dan tingkah laku kita. Akan tetapi, lingkungan kita yang aktual (yang sebenarnya) hanyalah faktor-faktor dalam dunia sekeliling kita, yang benar-benar secara langsung mempengaruhi pertumbuhan dan tingkah laku kita.

Sartain membagi lingkungan itu menjadi tiga bagian sebagai berikut:

1. lingkungan alam atau luar (extemal or physical enviroment) ialah segala sesuatu yang ada dalam dunia ini yang bukan manusia, seperti rumah, tumbuh-tumbuhan, air, iklim, dan hewan

2. lingkungan dalam (intemal environment) ialah segala sesuatu yang telah termasuk ke dalam diri kita, yang dapat mempengaruhi pertumbuhan fisik kita. Suatu makanan atau minuman yang telah kita makan dan berada di dalam perut kita, ia berada di antara lingkungan dalam dan lingkungan luar kita. Jika makanan telah dicerna dan sari-sari makanan itu telah diserap ke dalam pembuluh-pembuluh darah atau masuk ke dalam cairan limpa dan dengan demikian mempengaruhi pertumbuhan sel-sel di dalam tubuh, maka ia telah benar-benar termasuk ke dalam lingkungan dalam (intemd envirament) kita. Jadi, sesungguhnya sangat sukar bagi kita untuk menarik batas yang tegas antara "diri kita sendiri" dengan "lingkungan kita".

3. lingkungan sosial (scial enviroment) ialah semua orang atau manusia lain yang kita terima secara langsung dan ada yang tidak langsung. Pengaruh secara langsung, misalnya, dalam pergaulan sehari-hari dengan orang lain, dengan keluarga kita, teman-teman kita, kawan sekolah, kawan sepekejaan, dan sebagainya. Yang tidak langsung, melalui radio, televisi, dengan membaca buku-buku, majalah-majalah, surat-suarat kabar, dan sebagainya, dan dengan berbagai cara yang lain.

\section{Realita Problem}

Penyelenggaraan pendidikan adalah menjadi tanggung jawab bersama antara keluarga, masyarakat dan pemerintah, karena itu pendidikan berlangsung seumur hidup (longlifeedration) dan dilaksanakan di dalam lingkungan keluarga, 
sekolah dan masyarakat. Pendidikan kita terdin atas tiga bagian. Pertama, pendidikan informal (keluarga), formal (sekolah) dan nonformal (masyarakat). Sasaran yang ingin dicapai dari pendidikan kita adalah pembentukan aspek kognitif (intelektual), afektif (sikap mental atau moral) dan psikomotorik (skill/keterampilan). Idealnya, pembentukan aspek kognitif menjadi tugas dan tanggung jawab para pendidik (guru) di sekolah, pembentukan aspek efektif menjadi tugas dan tanggung jawab orang tua dan pembentukan aspek psikomotorik menjadi tugas dan tanggung jawab masyarakat (lembaga-lembaga kursus, dan sejenisnya).

Dengan adanya pembagian tugas seperti ini, masalah pendidikan sebenarnya menjadi tanggung jawab semua pihak: orang tua, pendidik (guru) dan masyarakat. Pendidikan moral seperti agama, budi pekerti, etika, dan sejenisnya, menjadi tugas dan tanggung jawab orang tua. Pendidikan keterampilan seperti kursus komputer, bahasa asing, menjahit, dan sebagainya, menjadi tugas dan tanggung jawab masyarakat (lembaga-lembaga kursus). Sedangkan pendidikan iptek (ilmu pengetahuan dan teknologi) menjadi tugas dan tanggung jawab para pendidik (guru) di sekolah.

Tapi karena tidak setiap keluarga mampu memberikan pendidikan yang dimaksud dalam keluarga, maka sekolah sering merasa perlu untuk memberikan tanggung jawabnya untuk mengembangkan seluruh kemampuan siswa, sehingga sekolah sering memberikan muatan-muatan yang dapat bermanfaat bagi siswa (bukan kognitif saja). Dari lingkungan keluarga yang harmonis yang mampu memancarkan keteladanan kepada anak-anaknya, akan lahir anak-anak yang memiliki kepribadian dengan pola yang mantap. Masalah kemampuan ekonomi, broken home, rindu kampung, menerima tamu, dan kurang kontrol merupakan faktor penghambat belajar. ${ }^{6}$

Pendidikan keluarga berfungsi sebagai :

1. Sebagai pengalaman pertama masa kanak-kanak.

2. Menjamin kehidupan emosional anak.

3. Menanamkan dasar pendidikan moral.

4. Memberikan dasar pendidikan social.

5. Meletakkan dasar-dasar kependidikan agama bagi anak-anak.

${ }^{6} \mathrm{Ibd}, \mathrm{hlm} 19$. 
Pada umumnya sekolah sebagai lembaga pendidikan dan merupakan pusat kegiatan belajar mengajar dijadikan tumpuan dan harapan orang tua, keluarga, masyarakat, bahkan pemerintah. Karena itu, sekolah senantiasa memberikan pelayanan pendidikan, pengajaran, dan pelatihan yang bersifat ilmu pengetahuan dan teknologi (IPTEK), keterampilan, dan pembentukan sikap mental yang baik bagi peserta didiknya (IMTAQ). ${ }^{7}$

Dalam kegiatan pembelajaran ini, bukan hanya ditempuh melalui pendidikan formal melainkan informal. Lingkungan sekolah yang kondusif, sangat mendukung kenyamanan dan kelangsungan proses belajar mengajar di suatu sekolah. Perkembangan dunia yang cepat seiring dengan era globalisasi, menambah semakin besar ragam pengaruh lingkungan yang menerpa dunia pendidikan. Apalagi perkembangan teknologi informasi yang begitu melesat, hampir setiap pelajar punya handphonedan internet tersedia mudah dan relatif murah. Pengaruh kemajuan tetap ada dua dampak yaitu positif dan negatif. Pengaruh lingkungan yang ada di upayakan menekan dampak negatif dan mengembangkan dampak positif.

Model sekolah unggul dan terpadu menjamur di pelosok daerah, dimulai dari yang menyatakan berstandar nasional sampai internasional. Tidak menutup kemungkinan bahwa semua itu hasil keja sama antara guru dan siswanya. Perlu diketahui bahwa proses kegiatan belajar-mengajar, bukan hanya diperoleh dalam kelas, tapi bisa juga diperoleh di luar kelas. Para pelajar bisa belajar bersama dengan memberdayakan lingkungan sekolah yang nyaman dan indah. Tidak sedikit sekolah yang kondisinya memprihatinkan di negeri kita. Dimulai dari sarana dan prasarana yang kurang memadai sampai tenaga pendidik yang masih minim.8Sebagai pendidikan yang bersifat formal, sekolah menerima fungsi pendidikan berdasarkan asas-asas tanggung jawab yang meliputi :

1. Tanggung jawab formal kelembagaan sesuai dengan fungsi dan tujuan yang ditetapkan menurut ketentuan-ketentuan yang berlaku, dalam hal ini undang-undang pendidikan:UUSPN Nomor 2 Tahun 1989.

7 Made Wiryana, "Problem Sosial dan Tri Pusat Pendidikan", dalam http/ / uruwviryana-blospotcom/ (7 Mare 2015)

${ }^{8}$ Arianto Sam "Lingkungan Sakdah Dalam Era Gldbalisas", dalam http/ / uruwsobatbanu.blogspt.com/ 2015/ 1 (2 Maret 2015) 
2. Tanggung jawab keilmuan berdasarkan bentuk, isi, tujuan dan tingkat pendidikan yang dipercayakan kepadanya oleh masyarakat dan bangsa.

3. Tanggung jawab fungsional, ialah tanggung jawab professional pengelola dan pelaksana pendidikan yang menerima ketetapan ini berdasarkan ketentuan-ketentuan jabatannya. Tanggung jawab dan kepercayaan orang tua (masyarakat) kepada sekolah dan para guru. ${ }^{9}$

Dalam menjalani pendidikan di masyarakat biasanya anak mengalami kesulitan-kesulitan. Lingkungan fisik dan non-fisik yang kurang/tidak menguntungkan. Lingkungan yang demikian akan banyak menghambat anak dalam belajar. Lingkungan tetangga yang senang berjudi, penyabung ayam, pencopet, dan sebagainya akan mempengaruhi anak kearah perbuatan yang tidak baik pula.

Faktor lingkungan merupakan salah satu yang mempengaruhi proses pembelajaran seperti faktor organisasi kelas dan faktor iklim sosial-psikologis. Maksudnya keharmonisan hubungan antara orang yang terlibat dalam proses pembelajaran. Iklim sosial ini dapat terjadi secara internal atau eksternal. Iklim sosial-psikologis secara internal adalah hubungan antara orang yang terlibat dalam lingkungan sekolah, misalnya iklim sosial antara siswa dengan siswa, antara siswa dengan guru, antara guru dengan guru, bahkan antara guru dengan pimpinan sekolah. Iklim sosial-psikologis eksternal adalah keharmonisan hubungan antara pihak sekolah dengan dunia luar, misalnya hubungan sekolah dengan orang tua siswa, hubungan sekolah dengan lembaga-lembaga masyarakat, dan lain sebagainya.

Sekolah yang mempunyai hubungan yang baik secara internal, yang ditunjukkan oleh kerja sama antarguru, saling menghargai dan saling membantu, maka memungkinkan iklim belajar menjadi sejuk dan tenang sehingga akan berdampak pada motivasi belajar siswa. Sebaliknya, manakala hubungan tidak harmonis, iklim belajar akan penuh dengan ketegangan dan ketidaknyamanan sehingga akan memengaruhi psikologis siswa dalam belajar. Demikian juga sekolah yang memiliki hubungan yang baik dengan lembagalembaga luar akan menambah kelancaran program-program sekolah, sehingga

${ }^{9}$ Hasbullah, Dasar-dasar Ilmu Pendidikan (Jakarta: PT. Raja Grafindb Pesada, 1999), hlm 47. 
upaya-upaya sekolah dalam meningkatkan kualitas pembelajaran akan mendapat dukungan dari pihak lain. ${ }^{10}$

\section{Mengapa Problem Itu Terjadi (Analisis faktor)}

Dalam memberikan pengaruh terhadap perkembangan anak, lingkungan ada yang sengaja diadakan (usaha sadar) ada yang tidak usaha sadar dari orang dewasa yang normatif disebut pendidikan, sedangkan yang lain disebut pengaruh. ${ }^{11}$ Pendidikan anak di jaman kesejagatan dan modern ini tidaklah mudah. Di satu sisi jaman ini memberikan berbagai banyak kemajuan teknologi yang memun gkinkan anak-anak kita memperoleh fasilitas yang serba "canggih" dan "wah". Anak-anak sekarang sejak dini sudah mengenal HP, camera, dan berbagai peralatan yang amat jauh dengan jaman "aku si anak singkong". Kemajuan yang demikian cepat juga ditengarai membawa dampak negatif seperti tersedianya informasi negatif melalui media masa yang sulit untuk dihindari. Misalnya: porno, kekerasan, konsumer-isme, takhayul, klenik dan kemusyrikan melalui berbagai media informasi seperti internet, handphone, majalah, televisi dan juga vcd.

Sebagai salah satu lingkungan terjadinya kegiatan pendidikan, masyarakat mempunyai pengaruh yang besar terhadap berlangsungnya segala kegiatan yang menyangkut masalah pendidikan. Oleh karena itu bahan apa yang akan diberikan kepada anak didik sebagai generasi harus disesuaikan dengan keadaan dan tuntutan masyarakat dimana kegiatan pendidikan itu berlangsung. Pendidikan sendiri telah didefinisikan secara berbeda-beda oleh orang-orang yang berlainan sesuai dengan pendapatnya masing-masing. Tetapi semua pendapat itu bertemu dalam pandangan, bahwa "Pendidikan adalah suatu proses dimana suatu bangsa mempersiapkan generasi mudanya untuk menjalankan kehidupan dan untuk memenuhi tujuan hidup secara efektif dan efisien".

${ }^{10}$ Wina Sanjaya, Strategj Penbdajaran Beronientasi Standar Pioses Pendidkan (Jakarta: Kenana, 2008), hlm 57.

${ }^{11}$ Fuad Ihsan, Op Cit, hlm 16. 
Pendidikan lebih daripada sekedar pengajaran. Karena, pada kenyataannya, pendidikan adalah suatu proses dimana suatu masyarakat membina dan mengembangkan kesadaran diri di antara individu-individu. D engan kesadaran tersebut, suatu masyarakat dapat mewariskan kekayaan budaya atau pemikiran kepada generasi berikutnya, sehingga menjadi inspirasi bagi mereka dalam setiap aspek kehidupan. Seperti diketahui, bahwa setiap masyarakat masingmasing mempunyai cici-ciri yang berbeda satu sama lain. Beberapa hal dalam masyarakat yang sangat erat hubungannya dengan kegiatan pendidikan itu dilaksanakan, yaitu nilai-nilai sosial budaya serta dinamika ilmu pengetahuan, teknologi dan ekonomi. ${ }^{12}$

\section{E. Akibatnya}

Jika dalam lingkungan keluarga anak mengalami hambatan pendidikan seperti perhatian orang tua terhadap anak kurang, sosial ekonomi keluarga kurang mendukung, kasih sayang kurang, tidak ada rasa aman di dalam keluarga, kepercayaan orang tua terhadap anak kurang, inisiatif dan kreativitas anak tidak bisa dikembangkan, dan figur orang tua tidak bisa membangkitkan semangat bagi anak. Maka pendidikan di lingkungan keluarga yang berfungsi untuk memberikan dasar dan menumbuhkembangkan anak sebagai makhluk individu, sosial, susila dan religius tidak terwujud.

Kemudian di lingkungan sekolah, cara belajar mengajar yang kurang baik, bahan bacaan yang kurang, bahkan pelajaran yang tidak sesuai dengan kemampuan, penyelenggaraan pendidikan yang kurang baik, kepemimpinan pendidikan yang jelek dan lingkungan yang tidak menunjang kesemuanya akan menjadi penghambat peran sekolah dalam upaya pencapaian tujuan pendidikan nasional.

A pabila nilai yang dikembangkan oleh anak berbeda/ bertentangan dengan nilai/ adat yang ada di masyarakat, maka akan timbul "konflik nilai". Kalau terjadi hal yang demikian biasanya anak akan mengalami kesulitan dalam menyesuaikan diri terhadap lingkungan tersebut. Keadaan demikian biasanya akan berpengaruh terhadap upaya belajar anak.

${ }^{12}$ Moch. Syanif Hidayatullah, "Masyarakat Sebagai Lingkungen Pendidikan", dalamhttp/ / wuwkkampusislamcond index.php (2hlm 2015) 


\section{F. Solusi}

Dalam suatu sekolah dapat dikatakan sebagai sekolah yang memiliki tempat strategis, dengan lingkungan kondusif, bila memenuhi beberapa syarat.

1. Lingkungan fisik, meliputi di dalam kelas maupun di luar kelas. Lingkungan fisik dalam kelas meliputi sarana dan prasarana pendukung yang ada dalam ruang. Bentuk dari macam sarana dan prasarana disesuaikan dengan penggunaan ruang. Ruang kelas untuk belajar berbeda dengan ruang kelas untuk kegiatan praktikum seperti laboratorium. Alat-alat canggih seperti komputer/ internet secara online yang langsung bisa digunakan oleh para guru dan murid dan planning kedepan pihak sekolah bisa mengembangkan siswanya menjadi modern dalam berpikir lewat pendekatan "Lingkungan sekolah yang kondusif dalam ruangan". Ruang perpustakaan terdapat banyak buku. Kenyamanan dalam menghias ruang perpustakaan memungkinkan siswa betah di perpustakaan. Apalagi buku-buku tertata rapi dan dikelompokkan sesuai bidang ilmu, maka mudah mencari dan mendapatkan buku yang diinginkan. Keadaan ini sangat mendukung keberhasilan proses pembelajaran.

2. Lingkungan sosial, interaksi belajar mengajar antara guru dan siswa yang menyenangkan sangat memotivasi belajar siswa. Penerapan model-model pembelajaran yang beranekaragam, bervariasi dapat mengatasi kejenuhan siswa.

Pergaulan antar sesama teman hanus dilaksanakan secara harmonis. Dalam pergaulan harus pandai menyeleksi ajakan teman. Bila ajakan itu merupakan kegiatan yang merugikan, sebaiknya dihindan. Misalnya ia mengajak mengkonsumsi obat-obat terlarang, sebaiknya tidak dituruti, bila ia memaksa, maka pergi ke guru BP supaya ada pemecahannya. Terhindarnya pergaulan bebas antar siswa dan siswi, yang mengakibatkan remaja hamil di luar nikah.

Masyarakat sebagai salah satu lingkungan pendidikan diharapkan untuk peka dalam menyikapi perkembangan yang terjadi dalam lingkungannya. Dengan pembaruan nilai sosial budaya akan lahir generasi-generasi baru dalam masyarakat itu yang pada titik tertentu kemajuan ilmu pengetahuan dan teknologi, dan untuk selanjutanya melangkah ke tangga kemajuan ekonomi. Kemajuan-kemajuan ini mendorong terwujudnya peradaban baru, tatanan baru, 
dan sistem yang lebih canggih dari sebelumnya Untuk memudahkan itu, tentu butuh generasi yang canggih dan terlatih. D an itu harus disiapkan jauh-jauh hari mulai di lingkungan terkecil seperti keluarga. Di sanalah setahap demi setahap kemajuan suatu masyarakat dibangun secara tak sadar. Bagaimana pun bagus pendidikan yang didapat oleh anak didik, tanpa ada masyarakat di sekitar lingkungannya yang mendorongnya untuk maju, tentu pendidikan bagus yang didapatnya itu hanya sedikit guna.

Ada dua macam cara menggunakan lingkungan sebagai sumber pengajaran/ belajar: ${ }^{13}$

1. Membawa peserta didik dalam lingkungan dan masyarakat untuk keperluan pelajaran (karyawisata, service proet, shod camping interviu, survey).

2. Membawa sumber-sumber dari msyarakat ke dalam kelas pengajaran untuk kepentingan pelajaran (resarces persons benda-benda, seperti pameran atau koleksi).

Usaha-usaha lain yang dapat dilakukan untuk melaksanakan prinsip lingkungan di antaranya adalah:

Memberi pengetahuan tentang lingkungan peserta didik,

Mengusahakan agar alat yang digunakan berasal dari lingkungan yang dikumpulkan baik oleh guru maupun peserta didik,

Memberi kesempatan kepada peserta didik untuk melaksanakan penyelidikan sesuai dengan kemampuannya melalui bacaan-bacaan dan observasi, kemudian mengekspresikan hasil penemuannya dalam bentuk percakapan, karangan, gambar, pameran, perayaan, dan sebagainya.

Dorothy law mengatakan bahwa anak-anak belajar dari kehidupan keluarganya: ${ }^{14}$

Jika seorang anak hidup dalam suasana penuh kritik,

Ia belajar untuk menyalahkan. hlm 21 .

${ }^{13}$ A hmad Rohani HM, Pengddaan Pencajaran (Jakarta: Rindka ajpa, 2004),

${ }^{14}$ J.I.G.M Drost, S.J., Sekdlah: MengajarA tau Mendidik (Yogakarta: Kanisius 1998), hlm 175 
Jika seorang anak hidup dalam permusuhan,

Ia belajar untuk berkelahi.

Jika seorang anak hidup dalam ketakutan,

Ia belajar untuk gelisah.

Jika seorang anak hidup dalam belas kasihan diri,

Ia belajar mudah memaafkan dirinya sendiri.

Jika seorang anak hidup dalam ejekan,

Ia belajar untuk merasa malu.

Jika seorang anak hidup dalam kecemburuan,

Ia belajar untuk iri hati.

Jika seorang anak hidup dalam rasa malu,

Ia belajar untuk merasa bersalah.

Jika seorang anak hidup dalam semangat jiwa besar,

Ia belajar untuk percaya diri.

Jika seorang anak hidup dalam menghargai orang lain,

Ia belajar untuk setia dan sabar.

Jika seorang anak hidupnya diterima apa adanya,

Ia belajar untuk mencintai.

Jika seorang anak hidupnya dimengerti,

Ia belajar bahwa sangat baik untuk mempunyai cita-cita.

Jika seorang anak hidup dalam suasana adil,

Ia belajar akan kemurahan hati.

Jika seorang anak hidup dalam kejujuran dan sportivitas,

Ia belajar akan kebenaran dan keadilan.

Jika seorang anak hidup dalam rasa aman,

Ia belajar percaya kepada dininya dan percaya kepada orang lain.

Jika seorang anak hidup penuh persahabatan,

Ia belajar bahwa dunia ini merupakan suatu tempat yang indah untuk hidup.

Jika kita hidup dalam ketentraman,

Anak-anak kita akan hidup dalam ketenangan batin.

\section{G. Penutup}

Untuk mencapai suatu tujuan pendidikan tidak bisa terlepas dari faktorfaktor yang saling berkaitan satu sama lain. Salah satunya adalah faktor lingkungan di mana lingkungan sendiri masih saling memberi pengaruh antara satu dengan lainnya. Lingkungan keluarga yang merupakan tempat pertama anak mendapat pendidikan diharapkan dapat membentuk aspek afektif (sikap metal dan moral). Lingkungan sekolah diharapkan dapat membentuk aspek kognitif (intelektual) dan lingkungan masyarakat diharapkan dapat membentuk aspek psikomotorik (skill/keterampilan) anak. Maka ketiga aspek tersebut ada 
dalam lingkungan pendidikan informal, formal dan nonformal yaitu lingkungan keluarga, sekolah dan masyarakat.

\section{DAFTAR PUSTAKA}

Arianto Sam, "Lingkungan Sekolah Dalam Era Globalisasi", dalam http:/ / www.sobatbaru.blogspot.com/ 2015/ 1 (2 Maret 2015)

Drost, S.J.,J.I.G.M. Sekdah Mengjar Atau Mendidik. Y ogyakarta: Kanisius, 1998.

Hasbullah. Dasar-dasar Ilmu Pendidikan Jakarta: PT. Rajagrafindo Persada, 1999.

Ihsan, Fuad. Dasar-Dasar Kependidikan Jakarta: Rineka Cipta, 1996

Made Wiryana, "Problem Sosial dan Tri Pusat Pendidikan", dalam http:/ / www.wiryana-blogspot.com/ (7 Maret 2015)

Moch. Syarif Hidayatullah, "Masyarakat Sebagai Lingkungan Pendidikan", dalam http:/ / www.kampusislam.com/ index.php (2 hlm, 2015)

Purwanto, M. Ngalim. Ilmu Penddikan Teaitis dan Praktis. Bandung: PT. Remaja Rosdakarya, 2007.

Rohani HM, Ahmad. PengddaanPengjaran Jakarta: Rineka cipta, 2004.

Sanjaya, Wina. Strategi Pembelajaran Berorientasi Standar Proses Pendidikan. Jakarta: Kencana, 2008.

Suryosubroto, B. Beberapa Aspek Dasar-Dasar Kependidikan Jakarta: Rineka Cipta, 1996.

Tim Penyusun. Dasar-Dasar Ilmu Pendidikan Buku Panduan Mahasiswa. Jakarta: PT Gramedia Pustaka Utama, 1996. 